\title{
Natural and cultural heritage in mountain landscapes: towards an integrated valuation
}

\section{James D.M. Speed, Gunnar Austrheim , H. John B. Birks, Sally Johnson,} Mons Kvamme , Laszlo Nagy , Per Sjögren , Birgitte Skar , Duncan Stone , Eva Svensson \& Des B.A. Thompson

To cite this article: James D.M. Speed, Gunnar Austrheim , H. John B. Birks, Sally Johnson , Mons Kvamme , Laszlo Nagy , Per Sjögren , Birgitte Skar, Duncan Stone , Eva Svensson \& Des B.A. Thompson (2012) Natural and cultural heritage in mountain landscapes: towards an integrated valuation, International Journal of Biodiversity Science, Ecosystem Services \& Management, 8:4, 313-320, DOI: $10.1080 / 21513732.2012 .725226$

To link to this article: https://doi.org/10.1080/21513732.2012.725226

View supplementary material ¿

曲 Published online: 30 Nov 2012.

Submit your article to this journal

Џll Article views: 854

View related articles $\sqsubset$

Citing articles: 8 View citing articles 두 


\title{
Natural and cultural heritage in mountain landscapes: towards an integrated valuation
}

\author{
James D.M. Speed ${ }^{\text {* }}$, Gunnar Austrheim ${ }^{\mathrm{a}}$, H. John B. Birks ${ }^{\mathrm{b}, \mathrm{c}, \mathrm{d}}$, Sally Johnson ${ }^{\mathrm{e}}$, Mons Kvamme ${ }^{\mathrm{f}}$, Laszlo Nagy ${ }^{\mathrm{g}}$,
} Per Sjögren ${ }^{\mathrm{a}, \mathrm{h}}$, Birgitte Skar ${ }^{\mathrm{a}}$, Duncan Stone ${ }^{\mathrm{i}}$, Eva Svensson ${ }^{\mathrm{j}}$ and Des B.A. Thompson ${ }^{\mathrm{e}}$

\begin{abstract}
${ }^{a}$ Museum of Natural History and Archaeology, Norwegian University of Science and Technology, NO-7491 Trondheim, Norway; ${ }^{b}$ Department of Biology and Bjerknes Centre for Climate Research, University of Bergen, NO-5020 Bergen, Norway; ${ }^{c}$ Environmental Change Research Centre, University College London, London, WC1E 6BT, UK; ${ }^{d}$ School of Geography and the Environment, University of Oxford, Oxford, OX1 3QY, UK; ${ }^{e}$ Scottish Natural Heritage, Silvan House, 231 Corstorphine Road, Edinburgh EH12 7AT, UK; ${ }^{f}$ Bergen Museum, University of Bergen, NO-5020 Bergen, Norway; ${ }^{g}$ Programa de Grande Escala da Biosfera - Atmosferana Amazonia, Instituto Nacional de Pesquisa da Amazonia, Manaus, Brazil; ${ }^{h}$ Tromsø University Museum, University of Tromsø, NO-9037 Tromsø, Norway; ${ }^{i}$ Scottish Natural Heritage, Great Glen House, Leachkin Road, Inverness IV63 6XF, Scotland; ${ }^{j}$ Environmental Science, Karlstad University, SE-651 88 Karlstad, Sweden
\end{abstract}

\begin{abstract}
Mountain areas of Europe have been managed by humans for a long time, leading to a prevalence of semi-natural habitats in mountain landscapes today. These landscapes contain both natural and cultural heritage; however, natural and cultural heritage are rarely considered together when valuing landscapes and developing management plans in protected areas. Here we present a case study of seven protected areas in the mountains of Great Britain and Norway. We take a long-term perspective on landscape and land-use change and propose an integrated model of landscape valuation on the basis of combined natural and cultural heritage. Our model plots indicators of natural and cultural heritage along a gradient of land-use intensity, allowing simultaneous assessment and highlighting how valuation depends on what type of heritage is considered. We show that while contemporary land-use changes follow similar trajectories in Norway and Britain, different land-use histories mean that the loss of heritage differs between the regions. The model presented here thus allows for the consolidation of valuation based on both cultural and natural heritage in landscapes.
\end{abstract}

Keywords: land use; long term; intensity; Norway; Great Britain

\section{Introduction}

Landscapes exist along a gradient of utilisation intensity from natural through semi-natural to highly agriculturally improved and otherwise anthropogenically utilised land. Past land use has played a large role in determining today's landscape state in many regions of the world (Birks et al. 1988; Iverson 1988; Brown et al. 2000), greatly affecting biodiversity across many groups of taxa (Dupouey et al. 2002; Poschlod et al. 2005; Kleijn et al. 2009) and ecosystem services on a global scale (Foley et al. 2005). Further land-use changes are inevitable in the future (Vitousek 1994; Millennium Ecosystem Assessment 2005), and their importance is often understated. Predictions of how landuse changes will affect, for example, biodiversity are being produced (White et al. 1997; Jetz et al. 2007). However, impacts on natural heritage are not the sole concern when considering changes in landscapes; landscapes also contain cultural heritage, and the concepts of natural and cultural heritage are often blurred (e.g. Svensson 1998; Webb 1998; Fischer et al. 2008; Emanuelsson 2009). Natural and cultural heritage are consequently closely linked within landscapes and could be conceptualised as inseparable (Lockwood et al. 2006). Yet, these are typically managed separately (Lockwood et al. 2006), often based upon separate legislations. Moreover, the relative weighting of cultural and natural heritage in the assessment of landscape value is often unconsidered, and the valuation of landscapes tends to take a short-term perspective (Willis and Birks 2006). There is thus a need for a better developed framework for a common evaluation of both cultural and natural heritage in landscapes to facilitate sound management decisions.

Mountain landscapes are often perceived as being wilderness areas, and $90 \%$ of the Norwegian land designated as IUCN category II protected areas is mountainous. However, human utilisation of natural resources in the mountain regions of Europe has historically been high, particularly hunting and gathering, local-scale industrial production (e.g. tar, iron) and transhumance agriculture (Thompson et al. 2005). Land use, along with natural and environmental drivers of change such as climate change, is a determinant of landscape state, and hence the natural and cultural heritage within landscapes (Körner 2003; Emanuelsson 2009). The history of changing land use and the dynamic nature of landscapes highlights the importance of a long-term perspective to determine a basis for conservation and management of these mountain landscapes (Willis and Birks 2006).

The challenge of setting a conservation objective and hence the corresponding management activity is particularly relevant in protected areas, where management may be directed towards conserving a particular landscape 
state, certain land uses, biodiversity or selected cultural heritage. First, stakeholders may have conflicting views on conservation goals and land use, for example, the use of livestock grazing to maintain plant diversity in mountains (e.g. Austrheim and Eriksson 2001). Second, even if there is a consensus view on conservation, management actions might not be serving their goal if managers' perspectives on natural drivers and human influence are based on a short-term view that fails to take long-term patterns and processes into account (Willis and Birks 2006). Thus, a common framework, based on a long-term perspective, may be of value.

Biodiversity is generally seen to peak at low to moderate intensities of land use (as predicted by the intermediate disturbance hypothesis whereby species richness decreases at both high and low levels of disturbance (Grime 1973; Connell 1978)). However, in terms of conservation, not all species are of equal prominence; some are rarer than others and this is reflected by classifications such as the IUCN red list (Baillie et al. 2004; Rodrigues et al. 2006). Equally, there is species turnover along the land-use gradient, with some species or groups benefiting from higher land-use intensities (Van Wieren and Bakker 1998), while many rare species are predominantly found in habitats with a long-term history of low-intensity utilisation, such as seminatural hay meadows, traditionally managed heathlands or mountainous pastures. Such species may be lost following abandonment (Pykälä et al. 2005; Kålås et al. 2010). Thus, to maximise biodiversity across the landscape, a range of land uses may be required (Olsson et al. 2000). Human utilisation of landscapes has tended to increase over time in both extent and land-use intensity, increasing the cultural heritage values within landscapes. However, recent mechanised intensification and standardisation of agriculture has led to a loss of valued older cultural heritage (Vos and Meekes 1999). The cessation or abandonment of low-intensity land use may lead to the loss of associated landscape elements, which may include artefacts, monuments, habitats and species dependent on historical land uses (Vos and Meekes 1999; MacDonald et al. 2000). The value placed on these elements may vary between stakeholders and managers.

Cultural and natural heritage may be evaluated in various ways: for example, through objective valuation of natural heritage (the potential exists, e.g. through the use of diversity indices) and more subjective valuation of cultural heritage in landscapes. This may relate to the loss of cultural heritage if greater emphasis is put upon the objective valuation (Solymosi 2011). Natural heritage is often regarded somewhat independently of time (with a focus on diversity instead), while the evaluation of cultural heritage sites and monuments may be strongly based upon their age (Lowenthal 2005), for example, the automatic protection of cultural elements in Norway pre-dating the reformation in AD 1537. It has been recognised that landscape change impacts both cultural and natural heritage, but uniting the differing values has been challenging; Dramstad et al. (2001) have suggested integration of valuation through common patterns and processes such as heterogeneity. However, as ecological and cultural aspects of landscapes are functions of both past and present land use (Fairclough et al. 2002), we use a long-term perspective to take account of both natural and cultural heritage to value landscapes. To these ends, we consider seven protected areas in the mountains of Britain and Norway as case studies, supplementing the existing literature, to propose a model to facilitate the simultaneous valuation of natural and cultural heritage in landscapes.

\section{Methods}

\section{Case-study sites}

Protected areas within mountain regions were selected along a latitudinal gradient in Great Britain and Norway from $53^{\circ} \mathrm{N}$ to $69^{\circ} \mathrm{N}$ (Figure 1). The two countries were selected because of their proximity and similarities in

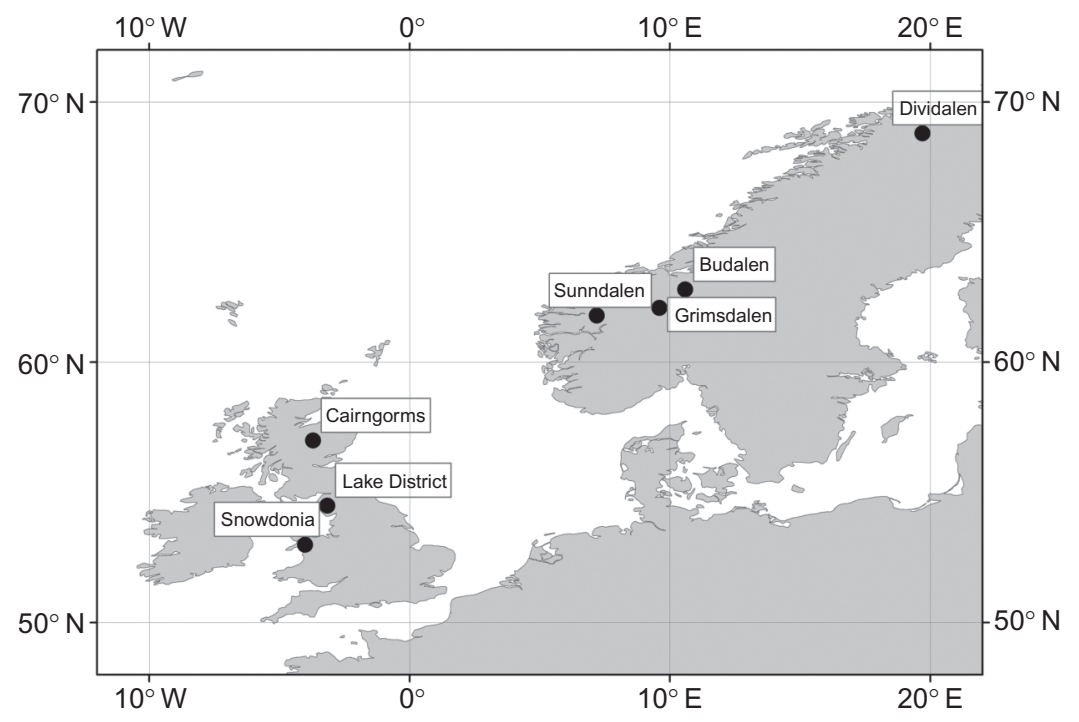

Figure 1. Location of study sites. 
land-use trends and climate (Edwards 2005). Protected upland sites have a large range of land-use intensity within the two countries. Three sites were selected in Great Britain: Snowdonia, Wales; the Lake District, England, and the Cairngorms, Scotland - all three are National Parks (NP) of IUCN category V (protected areas). In Norway, four sites were selected: (1) Sunndalen and Erdalen, (2) Grimsdalen, (3) Budalen and (4) Dividalen. Budalen and Grimsdalen are landscape conservation areas (LCA), while Sunndalen and Erdalen are two valleys within the Jostedalsbreen NP, and Dividalen is split between a NP and LCA. The Norwegian LCAs are IUCN category V, while the NPs are category II. Summary information for each site is presented in Table 1. All of the protected areas, both NPs and LCAs, were established to protect the natural and cultural heritage within the landscapes, and all are inhabited landscapes with resident human populations.

Around $30 \%$ of the land area of Norway lies above or north of the climatic tree-line, but land use such as summer farming and grazing by livestock and semi-domestic reindeer has caused an increase in open mountain area (Austrheim et al. 2010). Around 2.5\% of the United Kingdom is classified as subalpine or alpine (Bohn et al. 2004), but as in Norway, land use keeps a large area of the uplands of Britain in an unforested state. The NPs in Norway are generally at higher altitudes and tend to have much lower land-use intensities than the British NPs. For example, half of the Jostedalsbreen NP, of which the Sunndalen and Erdalen site forms a part, contains the Jostedal glacier. The other three Norwegian sites are LCAs. Norwegian LCAs tend to be conservation buffer regions between NPs and unprotected regions, with an intermediate level of legislation and management (Direktoratet for Naturforvaltning 2008). The selected regions are comparable between countries in terms of land use, despite the differences in designation.

\section{Data collection and evaluation}

A review of published and non-peer reviewed (grey) literature for each site provided information relating to (1) land use (prehistoric to contemporary), (2) the dominant landscape state (as characterised by the vegetation types within the landscape), (3) natural heritage and (4) cultural heritage within four time periods selected due to their relation to land-use phases among sites (3000 BC to AD 1750, 1750-1940, 1940-1980 and 1980-2010) for each of the seven sites (see the Supplementary Material). Indicators of natural and cultural heritage were then plotted against land use across landscape states. These indicators and wider processes relating to cultural and natural heritage that are affected by land use at different intensities are shown in Table 2.

There is generally a higher availability of data and information for the British sites than the Norwegian sites. In Norway, unprotected regions tend to be better monitored than protected areas, which are assumed to be free of threat (Blindheim et al. 2011). The best documented site is the

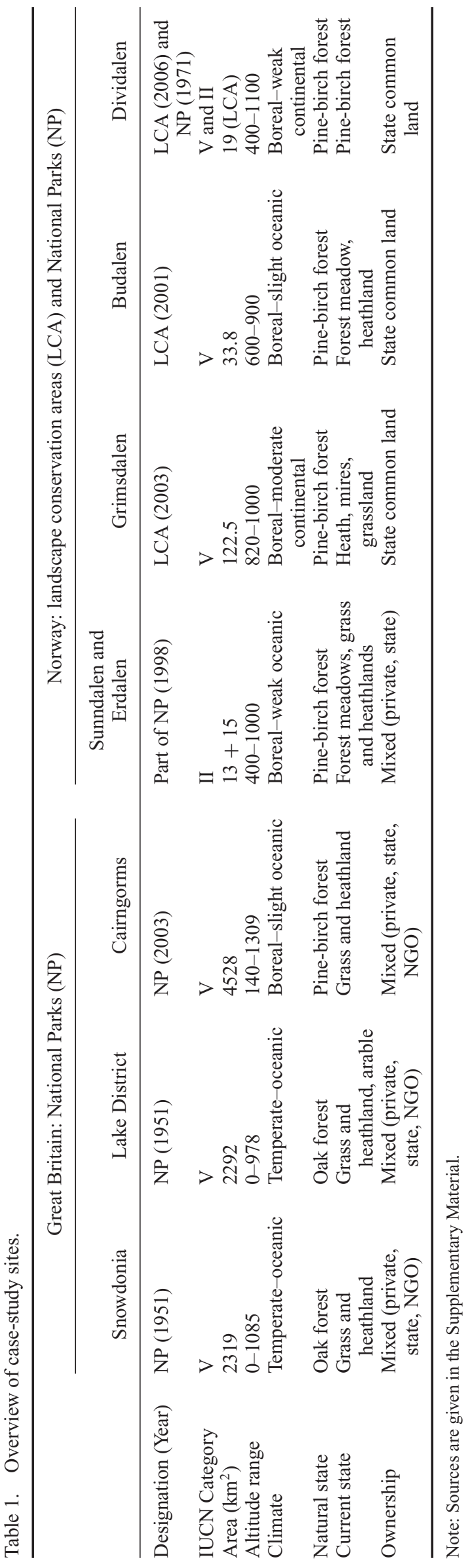


Table 2. Examples of elements and processes varying with land-use intensity and affecting natural and cultural heritage in landscapes.

\begin{tabular}{|c|c|c|}
\hline $\begin{array}{l}\text { Land-use } \\
\text { intensity }\end{array}$ & Natural heritage & Cultural heritage \\
\hline None & $\begin{array}{l}\text { Pristine habitats with relatively long continuity (old-growth forests, peat } \\
\text { bogs, etc.) } \\
\text { Natural successional dynamics }\end{array}$ & Generally negligible, some sacred sites ${ }^{\mathrm{a}}$ \\
\hline Low & $\begin{array}{l}\text { Increased number of habitats (open pastures, wood pastures, hay } \\
\text { meadows, etc.) } \\
\text { Most natural habitats intact (old-growth forests, peat bogs, etc. })^{\mathrm{a}}\end{array}$ & $\begin{array}{l}\text { Hunting traps }{ }^{\mathrm{b}} \\
\text { Culturally modified trees } \\
\text { Rock art }\end{array}$ \\
\hline Moderate & $\begin{array}{l}\text { Similar diversity of habitats } \\
\text { Meadows and pastures more abundant } \\
\text { Natural habitats less prevalent and more fragmented }\end{array}$ & $\begin{array}{l}\text { Fences and corrals } \\
\text { Roads and tracks } \\
\text { Traditional meadows and pastures }{ }^{\mathrm{bc}} \\
\text { Coppice woods }^{\mathrm{c}} \\
\text { Shielings }^{\mathrm{bc}}\end{array}$ \\
\hline High & $\begin{array}{l}\text { Monocultures (cultivated grassland, cereal fields, spruce plantations) } \\
\text { Clear cuts } \\
\text { Loss of micro-habitats (open ditches, clearance cairns, wood patches, } \\
\text { pathways, etc.) } \\
\text { Habitat fragmentation } \\
\text { Drainage of wetlands } \\
\text { Fertilisers } \\
\text { Overgrazing and erosion } \\
\text { Extermination of large predators } \\
\text { Extermination of competitive herbivores }\end{array}$ & $\begin{array}{l}\text { Industrialisation } \\
\text { Large economic units } \\
\text { Removal of (old) obstructing structures }\end{array}$ \\
\hline
\end{tabular}

Note: Some elements such as traditional pastures and meadows can be considered both as cultural and natural heritage. Case studies that are described in this issue are given in a Sjøgren and Kirchhefer (2012); ${ }^{b}$ Solem et al. (2012) and ${ }^{\mathrm{c}}$ Hjelle et al. (2012).

Cairngorms NP; this was most recently designated as a NP and the designation was accompanied by a major review of the area's resources (Shaw and Thompson 2006). However, as the Norwegian sites are smaller in area (Table 1), the information relating to them is more specific than for the larger British NPs, so the differences in data availability are assumed to have low impact on the study.

Several measures can be used to assess each of natural and cultural heritages. Natural heritage may be assessed in terms of pristineness, diversity (habitat richness, species richness or species' abundances), rarity, nativeness or abundance (Ratcliffe 1977). Similarly, cultural heritage can be valued in terms of age, condition, diversity (landscape richness, element richness or element abundance), rarity, source/ethnicity or abundance (English Heritage 1997; Labadi 2007). In this study, the criteria for comparable valuation of natural and cultural heritage were required. Natural heritage was thus assessed in terms of species richness, while cultural heritage was assessed in terms of the diversity of cultural elements. Importantly, intangible values could be associated with both natural and cultural aspects at any time stage, and are not included in the framework. No additional weight was given for rare or red-listed species nor rarity or age of cultural elements, since rarity may be transient. Further, equal importance was given to cultural and natural heritage and across the time range. These criteria were used to facilitate direct comparisons between natural and cultural heritage, through standardisation of values and integration. Trends in natural and cultural value were inferred from the shift along the cultural and natural heritage axes between the landscape states dominant in consecutive time periods.

\section{Results and discussion}

The dominant landscape states in protected Norwegian and British mountain areas are plotted in Figure 2. Trends in landscape state summarised across the selected protected areas within each country are also indicated using the four time periods. Across the protected areas, human influence is apparent from Neolithic times. Early land use from the Neolithic period involved utilisation of forests, nomadism, the establishment of some local-scale industrial production such as tar and iron and initiation of transhumance agriculture or summer farming (see the Supplementary Material). From the Neolithic to AD 1750, similar landscape states and land uses were assumed within the two countries (Figure 2). Early transhumance agriculture is likely to have taken the form of summer grazing in the mountain regions, along with the construction and utilisation of buildings inhabited during the summer grazing season (the upland residences are known as seter in Norway, shieling in England and Scotland and hafod in Wales; collectively referred to as summer farms herein). The combination of grazing, haymaking, burning and wood cutting led to a decrease in forest extent over this period in both countries. However, the loss of forest led to the creation of new seminatural habitats, and may have caused an increase in habitat diversity, and hence natural heritage, at low levels of disturbance (Figure 2), while cultural heritage also increased in value with a higher diversity of cultural elements.

From 1750, land use and landscape states diverged between the two countries. In Norway, the utilisation of summer farms intensified with increased exploitation of forests and increased densities of grazing livestock (see the Supplementary Material). This continued the trend of 


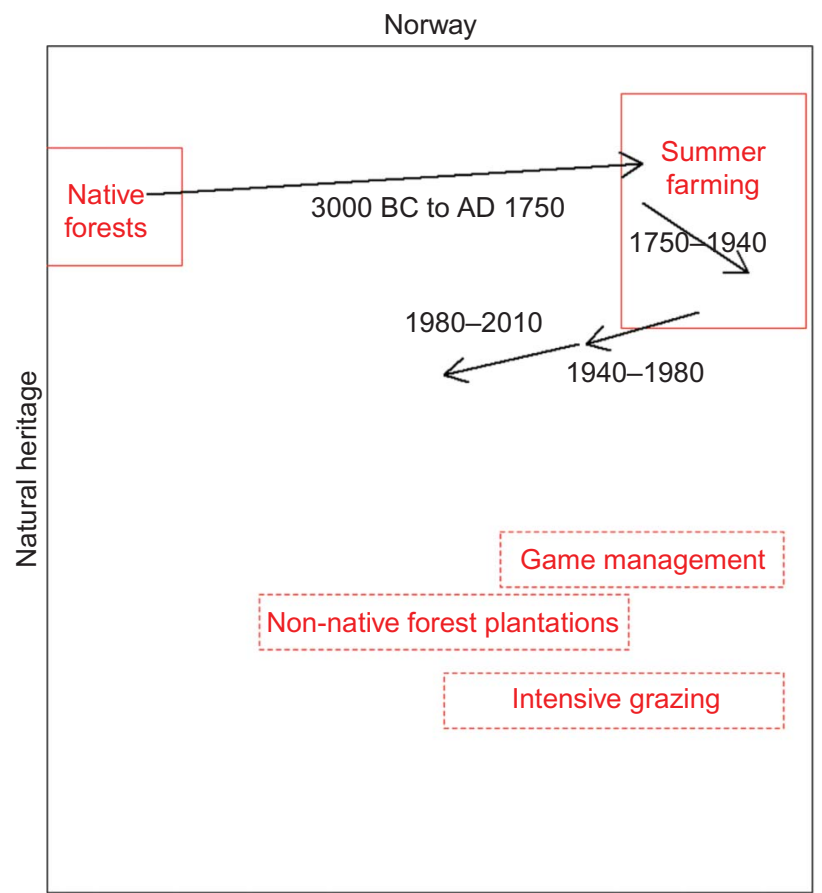

Cultural heritage

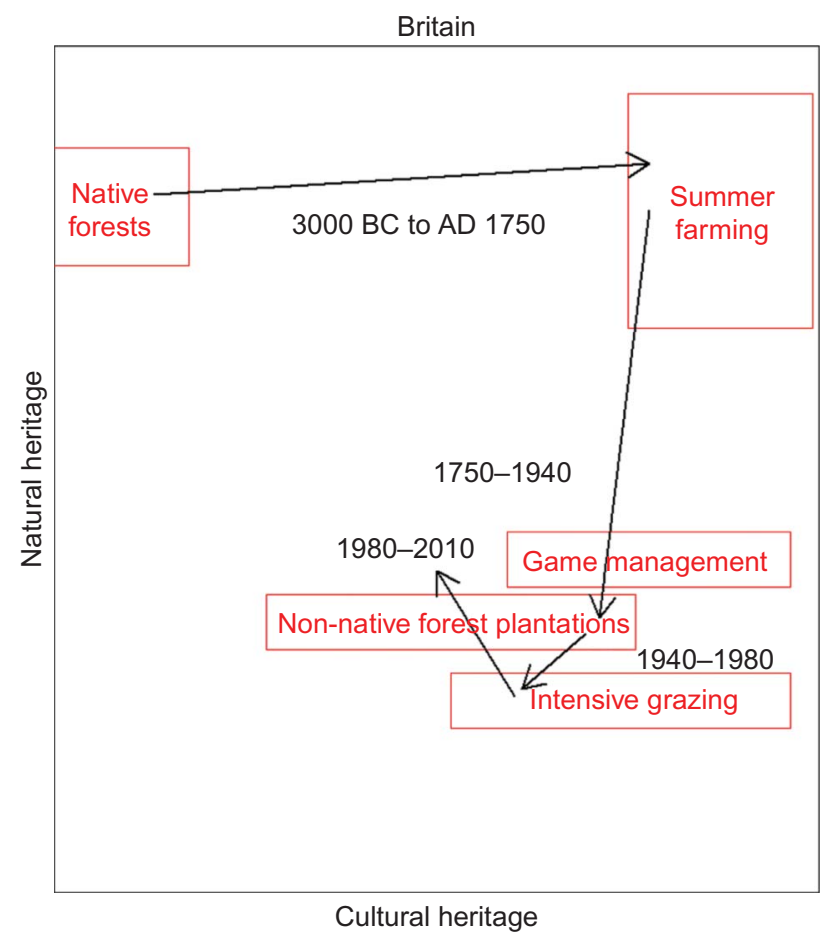

Figure 2. Apparent trends in land-use and landscape state in protected areas in Great Britain and Norway. The axes represent cultural and natural heritage (as defined in the text) associated with different landscape states. Boxes represent selected landscape states and land uses, dashed boxes indicate the landscape states and land-uses which were not common in that country. The arrows represent transitions within selected time periods in terms of cultural and natural heritage. The length of the boxes along each of the $x$ and $y$ axes reflects the variation in heritage that may be assigned to the landscape state.

increasing cultural heritage value without or with only minor declines in natural heritage value (Figure 2). In contrast, in Great Britain, land use intensified during this period, characterised by the enclosing of land, and management of upland landscapes for intensive livestock grazing or game species including red grouse (Lagopus lagopus scotica) and red deer (Cervus elaphus). In Snowdonia, the hafod system disintegrated through the enclosure of the uplands and the transfer of common land into private ownership. Overall, in Wales, 20\% of the entire land area, almost entirely uplands, was enclosed from 1760 to 1830 (Roberts 1959). In the Lake District, the shieling system declined earlier, perhaps by the 1650 s and a similar but more gradual transition towards larger tenancies and the modern hill farm took place (Whyte 2003). In the Cairngorms, as in the wider Highlands, the advent of sheep husbandry forced the reorganisation of farm tenancy arrangements and dismantled traditional society and farming in the sometimes forced emigration of transhumance populations known as the Highland Clearances. New leases directed tenants towards sheeponly management by banning horses, cattle and goats from the summer pastures (Bil 1990). This intensification was somewhat heterogeneous, with transitions towards extensive Calluna heathlands managed for grouse shoots in some places; while in others, a shift to Nardus grasslands (and a decline in natural heritage) is associated with increased grazing, as the dominant livestock in Great Britain upland sites shifted from cattle to sheep (Stevenson and Thompson 1993). Concurrently, the evictions of transhumance populations led to a loss of cultural heritage (Figure 2).

The trend for increasing intensification in the British uplands continued from 1940 to 1980 (Figure 2), with the proliferation of non-native plantation forestry, commonly spruce (Picea sitchensis and Picea abies). The biodiversity associated with plantation forests is generally well below that of native forests, although there is an increasing recognition that plantations contribute to biodiversity for a range of taxa (Quine and Humphrey 2010), albeit to a low degree. In Norway, the number of active summer farms peaked in the 1850s (Reinton 1955). However, a continuous change in summer farming practices during the twentieth century, including the establishment of industrial milk processing, reduction in spring-born calves and shift from dairy livestock to meat producing livestock (heifers and sheep), decreased the demand for fuel-wood and fodder resources in the summer farm regions (Almaas 2004). The decline in cultural landscape elements associated with transhumance land use started mainly after 1945, including semi-natural grasslands as shrubs and trees recolonised open landscapes previously maintained by land use (Hofgaard 1997; Speed et al. 2010). Natural heritage declines as species associated with traditional land use are lost while the encroaching forests usually lack the species associated with the original ancient forests and thus has a correspondingly lower natural heritage value (Figure 2). 
Since 1980, the abandonment of summer farms has continued in the Norwegian sites, with a continuing high loss of cultural and natural heritage (Figure 2). In Great Britain, changes have been more contradictory, with both continuing intensive land use in some regions and decreased densities of grazing livestock in others. Concurrently, conservation management has proliferated, with active reforestation of native woodlands. Thus, the direction of landscape change and value of cultural and natural heritage is more locally variable in Great Britain during this time period (Figure 2).

\section{Towards an integrated valuation of cultural and natural heritage}

The conceptual model proposed to aid the valuation of landscapes in protected mountain areas in Great Britain and Norway was based on landscape states within the seven protected mountain area case-study sites, spanning from the Neolithic to present (Figure 3). The implied value of both natural and cultural heritage indicators was plotted along a gradient of land-use intensity, from a landscape devoid of humans to a highly utilised landscape. In this model, cultural heritage, reflecting the richness of cultural elements in the study areas (including artefacts such as the remains of pitfall traps, buildings and culturally-modified landscapes), is assumed to rise from zero in the absence of human influence to peak at mid-high land-use intensity, and to decrease at higher land-use intensity as further intensification leads to amalgamation of farms. Natural heritage, reflecting species richness, is high in the absence of human influence and at low land-use intensities, but decreases at higher land-use intensities (with pasture improvement and loss of old meadows), reflecting the predictions of the intermediate disturbance hypothesis.

The shape of the curves shown in Figure 3 is not definitive; the exact shape will vary between regions, land-uses and contexts. However, the conceptual model is adaptable to other systems, and as a tool, may be of value to help resolve conflicts by visualising stakeholders' values (i.e.

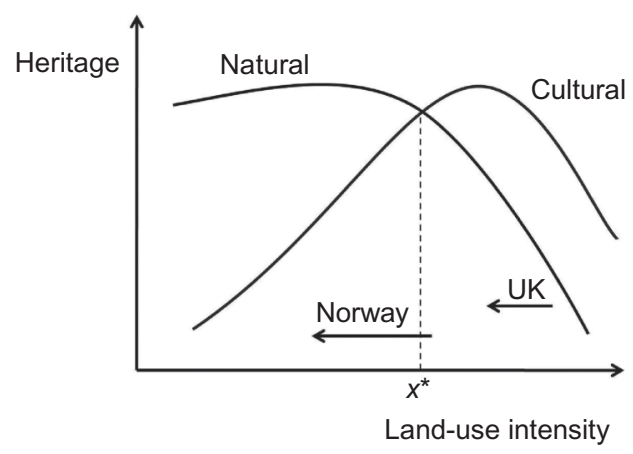

Figure 3. A conceptual model of how cultural and natural heritage vary along a gradient of land-use intensity in protected areas in north-west European mountain regions. $x^{*}$ indicates the landuse intensity at which the sum of cultural and natural heritage peak. Recent trends in landscape change in Great Britain and Norway are denoted by arrows. by showing the position along a gradient of land-use intensity that the stakeholder perceives the peak landscape value to lie) and by putting landscape changes in the context of historical trajectories of land use. Furthermore, the model presented has the potential to include other means of valuation (e.g. economic productivity or ecosystem services) by simply adding a further curve describing the trend in value with land-use intensity for the system in question. Different measures of valuation could be equally weighted by ensuring that the area under each curve is equal, or alternatively the values of the different measures could be standardised as a proportion of the maximum potential value in the area being assessed. The model has the potential to be used either quantitatively or qualitatively.

This model allows us to identify the land-use intensity for which natural and cultural heritage peak, as well as a valuation integrating cultural and natural heritage to be estimated ( $x^{*}$ in Figure 3 ). Hence, changes in landscape state along more than one heritage gradient can be simultaneously assessed. In the case-study sites, natural heritage peaks at a lower land-use intensity than cultural heritage, although an intermediate land-use intensity can give high natural and cultural heritage. This model can thus be used to visualise the aims of different stakeholders, although it should be noted that the peak will depend on the stakeholders' valuation of the landscapes' heritage. Further, the land-use intensity of the peak-integrated cultural and natural heritage may fall at a non-stable state. Thus, other factors such as management feasibility still need to be considered in developing management plans.

Recent trends in landscape change across the casestudy protected areas within the two countries are shown in the conceptual model (Figure 3). These trends in landscape change are in the same direction in each country, but changes in natural and cultural heritage also differ between countries, due to the different starting points. The different starting points are influenced by the contrasting land-use history (from AD 1750 onwards) in protected mountain areas in the two countries.

\section{Conclusion}

This study highlights the importance of land use as driver of both natural and cultural heritage in mountain landscapes, and also illustrates the potential loss of heritage at both intensified and reduced land use from the current situation in both the United Kingdom and Norway. Here we have highlighted how differing historic land uses determine the current landscape states in protected mountain areas in north-west Europe. Although changes in land use show a similar trajectory of extensification in both Norway and Great Britain, the land-use history means that cultural and natural heritage may be changing in different directions (Figure 2). As a landscape state is caused by past land use in these regions, the importance of taking a long-term perspective is paramount to contextualise contemporary change (Emanuelsson 2009). The study also shows that 
the valuation of mountain landscapes varies depending on whether natural heritage, cultural heritage or both are taken onto account. The main challenge for management in protected mountain areas is thus to find a sustainable land use using an integrated perspective such as that presented here.

The model proposed here demonstrates a method for visualising both past landscape states and landscape valuation according to different types of heritage. By including differing types of heritage, this approach can support an integrated valuation of landscapes. This model developed for protected mountain areas with histories of human use allows assessment of landscapes on the basis of integrated cultural and natural heritage and to assess contemporary changes against historical changes. This model is extendable to include other aspects such as economic or ecosystem services and could be adapted to the valuation of other systems. Other measures of valuation as further functions of land-use intensity could also be used. Both natural and cultural heritage are ultimately based on value judgements, and thus involve some subjectivity, if only in terms of the selection of the measure used to assess value. While the presented model thus cannot remove subjectivity in valuation, it can visualise and conceptualise the applied valuation within the landscape, and facilitate management decisions by showing the loss of heritage under different scenarios.

\section{References}

Almaas R. 2004. Norwegian agricultural history. Trondheim (Norway): Tapir Akademiske Forlag.

Austrheim G, Bråthen KA, Ims RA, Mysterud A, Ødegaard F. 2010. Alpine environment. In: Kålås JA, Henriksen S, Skjelseth S, Viken Å, editors. Enviornmental conditions and impacts for red list species. Trondheim (Norway): Norwegian Biodiversity Information Centre. p. 107-118.

Austrheim G, Eriksson O. 2001. Plant species diversity and grazing in the Scandinavian mountains - patterns and processes at different spatial scales. Ecography. 24(6):683-695.

Baillie JEM, Hilton-Taylor C, Stuart SN 2004. IUCN red list of threatened species: a global species assessment. Gland (Switzerland) and Cambridge (UK): IUCN.

Bil A. 1990. The shieling, 1600-1840: the case of the central Scottish Highlands. Edinburgh (Scotland): John Donald.

Birks HH, Birks HJB, Kaland P, Moe D, editors. 1988. The cultural landscape - past, present and future. Cambridge (UK): Cambridge University Press.

Blindheim T, Thingstad PG, Gaarder G. 2011. Naturfaglig evaluering av norske verneområder. Dekning av naturtyper og arter, NINA Rapport 539. Oslo (Norway): Norsk institutt for naturforskning.

Bohn U, Gollub F, Hettwer C, Neuhauslova Z, Raus T, Schlueter H, Weber H. 2004. Map of the natural vegetation of Europe. Scale 1: 2500 000. Part I. Explanatory text with CD-ROM. Bundesamt für Naturschutz, Bonn, Germany.

Brown DG, Pijanowski BC, Duh JD. 2000. Modeling the relationships between land use and land cover on private lands in the Upper Midwest, USA. J Environ Manag. 59(4): 247-263.

Connell JH. 1978. Diversity in tropical rain forests and coral reefs. Science. 199(4335):1302-1310.

Coombes, PMV, Chiverrell, RC, Barber, KE. 2008. A high resolution pollen and geochemical analysis of late Holocene human impact and vegetation history in Southern Cumbria, England. J Quat Sci. 24(3):224-236.

Direktoratet for Naturforvaltning. 2008. Områdevern og forvaltning. Trondheim (Norway): Direktoratet for Naturforvaltning.

Dramstad WE, Fry G, Fjellstad WJ, Skar B, Helliksen W, Sollund MLB, Tveit MS, Geelmuyden AK, Framstad E. 2001. Integrating landscape-based values - Norwegian monitoring of agricultural landscapes. Landsc Urban Plann. 57(3-4):257-268.

Dupouey JL, Dambrine E, Laffite JD, Moares C. 2002. Irreversible impact of past land use on forest soils and biodiversity. Ecology. 83(11):2978-2984.

Edwards ME. 2005. Landscape history and biodiversity conservation in the uplands of Norway and Britain: comparisons and contradictions. In: Thompson DBA, Price MF, Galbraith CA, editors. Mountains of Northern Europe: conservation, management, people and nature. Edinburgh (Scotland): TSO Scotland.

Emanuelsson U. 2009. The rural landscapes of Europe: how man has shaped European nature. Stockholm (Sweden): Swedish Research Council Formas.

English Heritage. 1997. Sustaining the historic environment: new perspectives on the future: an English Heritage discussion document. London (UK): English Herigate.

Fairclough GJ, Lambrick G, Hopkins D. 2002. Historic landscape characterisation in England and a Hampshire case study. In: Fairclough GJ, Rippon SJ, editors. Europe's cultural landscape: archaeologists and the management of change. Brussels (Belgium): Europae Archaeologiae Consilium and English Heritage. p. 69-83.

Fischer M, Rudmann-Maurer K, Weyand A, Stöcklin J. 2008. Agricultural land use and biodiversity in the Alps. Mt Res Dev. 28(2):148-155.

Foley JA, DeFries R, Asner GP, Barford C, Bonan G, Carpenter SR, Chapin FS, Coe MT, Daily GC, Gibbs HK, et al. 2005. Global consequences of land use. Science. 309(5734):570-574.

Grime JP. 1973. Competitive exclusion in herbaceous vegetation. Nature. 242(5396):344-347.

Hjelle K, Kaland S, Kvamme M, Lødøen T, Natlandsmyr B. 2012. Ecology and long-term land-use, palaeoecology and archaeology - the usefulness of interdisciplinary studies for knowledge-based conservation and management of cultural landscapes. Int J Biodivers Sci Ecosyst Serv Manag. 8(4):321-337.

Hofgaard A. 1997. Inter-relationships between treeline position, species diversity, land use and climate change in the central Scandes Mountains of Norway. Glob Ecol Biogeogr. 6(6):419-429.

Iverson LR. 1988. Land-use changes in Illinois, ASA: the influence of landscape attributes on current and historic land use. Landsc Ecol. 2(1):45-61.

Jetz W, Wilcove DS, Dobson AP. 2007. Projected impacts of climate and land-use change on the global diversity of birds. PLoS Biol. 5(6):e157.

Kålås JA, Viken Å, Henriksen S, Skjelseth S. 2010. The 2010 Norwegian red list for species. Trondheim (Norway): Norwegian Biodiversity Information Centre.

Kleijn D, Kohler F, Baldi A, Batary P, Concepcion ED, Clough Y, Diaz M, Gabriel D, Holzschuh A, Knop E, et al. 2009. On the relationship between farmland biodiversity and land-use intensity in Europe. Proc R Soci B: Biol Sci. 276(1658):903-909.

Körner C. 2003. Alpine plant life: functional plant ecology of high mountain ecosystems. Berlin (Germany): SpringerVerlag.

Labadi S. 2007. Representations of the nation and cultural diversity in discourses on World Heritage. J Soc Archaeol. 7(2):147-170. 
Lockwood M, Worboys G, Kothari A. 2006. Managing protected areas: a global guide. London (UK): Earthscan.

Lowenthal D. 2005. Natural and cultural heritage. Int J Herit Stud. 11(1):81-92.

MacDonald D, Crabtree JR, Wiesinger G, Dax T, Stamou N, Fleury P, Gutierrez Lazpita J, Gibon A. 2000. Agricultural abandonment in mountain areas of Europe: environmental consequences and policy response. J Environ Manag. 59(1):47-69.

Millennium Ecosystem Assessment. 2005. Ecosystems and human well-being: synthesis. Washington (DC): World Resources Institute.

Olsson EGA, Austrheim G, Grenne SN. 2000. Landscape change patterns in mountains, land use and environmental diversity, Mid-Norway 1960-1993. Landsc Ecol. 15(2): 155-170.

Poschlod P, Bakker JP, Kahmen S. 2005. Changing land use and its impact on biodiversity. Basic Appl Ecol. 6(2): 93-98.

Pykälä J, Luoto M, Heikkinen RK, Kontula T. 2005. Plant species richness and persistence of rare plants in abandoned seminatural grasslands in northern Europe. Basic Appl Ecol. 6(1):25-33.

Quine C, Humphrey J. 2010. Plantations of exotic tree species in Britain: irrelevant for biodiversity or novel habitat for native species? Biodivers Conserv. 19(5):1503-1512.

Ratcliffe DA. 1977. A nature conservation review: volume 1: the selection of biological sites of national importance to nature conservation in Britain. Cambride (UK): Cambridge University Press.

Reinton OL. 1955. Sæterbruket i Norge I. Sæterbrukstypar og driftsformer. Oslo (Norway): H. Aschehoug \& Co.

Rhind P, Jones, B. 2003. The vegetation history of Snowdonia since the late Glacial period. Field Studies. 10:539-552.

Risbøl O, Stene K, Sætren A, editors. 2011. Kultur og natur i Grimsdalen landskapsvernområde. Sluttrapport fra DYLANprosjektet. - NIKU Tema 38

Roberts RA. 1959. Ecology of human occupation and land use in Snowdonia. J Ecol. 47(2):317-323.

Shaw P, Thompson DBA, editors. 2006. The nature of the cairngorms. Edinburgh (Scotland): Diversity in a changing environment. The Stationery Office Ltd.
Sjögren P, Kirchhefer A. 2012. Historical legacy of the oldgrowth pine forest in Dividalen, northern Scandes. Int J Biodivers Sci Ecosyst Serv Manag. 8(4):338-350.

Solem T, Aune E, Daverdin M, Hassel K, Sjögren P, Stenvik L, Tretvik AM, Øien D-I, Austrheim G. 2012. Long-term land use and landscape dynamics in Budalen, central Norway. Int J Biodivers Sci Ecosyst Serv Manag. 8(4):351-359.

Solymosi K. 2011. Indicators for the identification of cultural landscape hotspots in Europe. Landsc Res. 36(1):3-18.

Speed JDM, Austrheim G, Hester AJ, Mysterud A. 2010. Experimental evidence for herbivore limitation of the treeline. Ecology. 91(11):3414-3420.

Stevenson AC, Thompson DBA. 1993. Long-term changes in the extent of heather moorland in upland Britain and Ireland: palaeoecological evidence for the importance of grazing. Holocene. 3(1):70-76.

Thompson DBA, Price MF, Galbraith CA, editors. 2005. Mountains of Northern Europe: conservation, management, people and nature. Edinburgh (Scotland): The Stationary Office Ltd.

Van Wieren SE, Bakker JP. 1998. Grazing for conservation in the twenty-first century. In: WallisDeVries MF, Bakker JP, Van Wieren SE, editors. Grazing and conservation management. Dordrecht (The Netherlands): Kluwer Academic Publishers. p. 349-363.

Vitousek PM. 1994. Beyond global warming: ecology and global change. Ecology. 75(7):1861-1876.

Vos W, Meekes H. 1999. Trends in European cultural landscape development: perspectives for a sustainable future. Landsc Urban Plann. 46(1-3):3-14.

Webb NR. 1998. The traditional management of European heathlands. J Appl Ecol. 35(6):987-990.

White D, Minotti PG, Barczak MJ, Sifneos JC, Freemark KE, Santelmann MV, Steinitz CF, Kiester AR, Preston EM. 1997. Assessing risks to biodiversity from future landscape change. Conserv Biol. 11(2):349-360.

Whyte I. 2003. Wild, barren and frightful'-parliamentary enclosure in an upland county: Westmorland 1767-1890. Rural History. 14(1):21-38.

Willis KJ, Birks HJB. 2006. What is natural? The need for a long-term perspective in biodiversity conservation. Science. 314(5803):1261-1265. 